\title{
Desain Kelembagaan Satuan Pengawas Internal (SPI) di STAIN Curup (Sebuah Penawaran Desain SPI untuk Efektivitas dan Efisien Pengelolaan Keuangan, Kinerja Pegawai dan Aset Negara)
}

\author{
Sugiatno \\ Sekolah Tinggi Agama Islam Negeri (STAIN) Curup \\ staincurupsugiatno@gmail.com
}

\begin{abstract}
Internal Supervisory Unit (SPI) is a quality assurance unit that exist in every Islamic University. Internal Supervisory Unit (SPI) STAIN Curup is an element of supervisor who performs nonacademic field supervision functions for and on behalf of University Leaders. The scope of non-academic field supervision includes: (1) finance, (2) asset, and (3) buman resources (HR). After the establishment of the internal supervisory unit (SPI) at STAIN Curup since september 2017 ago until now has not been able to perform its functions to conduct internal supervision and audit. Since the institutional or organizational structure does not have organizational structure, vision and mission, authority and responsibility and lack of internal auditor performance guidance to be conducted in the framework of evaluation of non-academic field activities including audit planning activities, testing and evaluating information, audit result notification and acts further audit results. This type of research is field research (fileld research), in this case the researcher uses descriptive qualitative research type that is analyzing and presenting the facts systematically based on the number or amount of data mendepenelitiankan in the form of data for the understood and concluded. this research is comparative descriptive research in the form of concept study. From the aspect of the objectives, this research is a study that attempted to describe the substance of the analysis of the concept of the formulation of the Design of Institution of Internal Control Unit (SPI) at STAIN Curup (an SPI design offer for effectiveness and efficient financial management, employee performance and state assets). The result of this research is: The existence of Internal Supervisory Unit at STAIN Curup is a must again after the issuance of Regulation of the Minister of Religious Affair No. 25 year 2017 dated 04 August 2017 about Internal Supervisory Unit (SPI) at State Religious College. The design of vision, mission, purpose, function, authority, and Structure of STAIN Curup has been formulated based on the FGD and KMA results dated 04 August 2017. Internal Auditor Performance Internal Audit Unit (SPI) STAIN Curup can be seen from four audit execution, namely: a ). Audit planning stage, b). Testing and evaluation phase of information, c). Stage of delivery of audit result, d). Follow-up phase of audit.
\end{abstract}

Keywords : Internal Control Unit, Effectiveness, Efficiency

Abstrak : Satuan Pengawas Internal (SPI) merupakan unit penjamin mutu yang ada disetiap Perguruan Tinggi Islam. Satuan Pengawasan Internal (SPI) STAIN Curup merupakan unsur pengawas yang menjalankan fungsi pengawasan bidang non-akademik untuk dan atas nama Pemimpin Perguruan Tinggi. Ruang lingkup pengawasan bidang non-akademik meliputi: (1) bidang keuangan, (2) bidang asset, dan (3) bidang Sumber Daya manusia (SDM). Setelab dibentuknya satuan pengawas internal (SPI) di STAIN Curup sejak bulan september 2017 yang lalu bingga sekarang belum dapat melaksanakan fungsinya melakukan pengawasan dan audit internal. Dikarenakan secara kelembagaan atau keorganisasian belum memiliki struktur keorganisasian, visi dan misi, wewenang dan tanggungjawab dan belum adanya panduan kinerja internal auditor yang harus dilakukan dalam rangka evaluasi terhadap kegiatan bidang nonakademik, yang meliputi kegiatan perencanaan audit, pengujin dan pengevaluasian informasi, pemberitabuan hasil audit dan tindak lanjut hasil audit. Jenis penelitian ini adalah penilitian lapangan (fileld research), dalam hal ini peneliti menggunakan jenis penelitian deskriftif kualitatif yaitu menganalisis dan menyajikan fakta secara sistematik berdasarkan jumlab atau banyaknya data yang didepenelitiankan dalam bentuk data-data untuk di pahami dan disimpulkan. penelitian ini merupakan penelitian comparative descriptive dalam bentuk studi konsep (concept studies). Sementara dari aspek tujuannya, penelitian ini adalab penelitian yang mencoba menggambarkan substansi analisis konsep formulasi Desain Kelembagaan Satuan Pengawas Internal (SPI) di STAIN Curup (sebuah penawaran desain SPI untuk efektivitas dan efisien pengelolaan keuangan, kinerja pegawai dan aset negara). Hasil penelitian ini adalah : Keberadaan Satuan Pengawas Internal di STAIN Curup merupakan suatu keharusan terlebih lagi setelah keluarnya Peraturan Menteri Agama RI Nomor 25

TADBIR : Jurnal Studi Manajemen Pendidikan vol. 2, no. 1, Juni 2018

STAIN Curup - Bengkulu | p-ISSN 2580-3581; e-ISSN 2580-5037 
tabun 2017 tertanggal 04 Agustus 2017 tentang Satuan Pengawas Internal (SPI) pada Perguruan Tinggi Keagamaan Negeri. Desain visi, misi, tujuan, fungsi, kewenangan, dan Struktur SPI STAIN Curup telah dirumuskan berdasarkan kepada hasil FGD dan KMA tertanggal 04 Agustus 2017. Kinerja Auditor Internal satuan pengawas internal (SPI) STAIN Curup dapat dilibat dari empat pelaksanaan audit, yaitu : a). Tahap perencanaan audit, b). Tahap pengujian dan pengevaluasian informasi, c). Tahap penyampaian hasil audit, d). Tahap tindak lanjut (follow up) hasil audit.

Kata Kunci : Satuan Pengawas Internal, Efektivitas, Efensiensi

\section{Pendahuluan}

Peraturan Menteri Agama republik Indonesia Nomor 31 Tahun 2016 tentang Statuta Sekolah Tinggi Agama Islam Negeri (STAIN) Curup bagian keempat pasal 29 mengisyaratkan bahwa STAIN Curup harus memiliki standar pelayanan yang harus dicapai dalam setiap aspek kegiatannya. Untuk mencapai standar tersebut STAIN Curup harus dikelola secara efektif, efisien dan akuntabel.

Disamping itu, STAIN Curup memiliki tujuan untuk mencapai Visi dan Misi dengan menjalankan tata kelola organisasi yang baik dan benar sehingga akan menghasilkan pengelolaan yang bermutu. Dalam pengelolaan STAIN Curup sebagaimana sebuah organisasi, juga rawan terjadi penyimpangan-penyimpangan. Seperti penyimpangan terhadap pengelolaan administrasi keuangan dan aset, bisa menjadi ancaman tindak kecurangan atau korupsi. Apapun bentuk penyimpangannya, potensial akan menimbulkan kerugian terhadap nmasyarakat dan negara.

Dengan semangat reformasi birokrasi, penguatan tata kelola dan akuntabilitas di lingkungan STAIN Curup dan dalam rangka mewujudkan Good Governance, maka perlu dibentuk Satuan Pengawasan Internal (SPI) STAIN Curup. Satuan Pengawas Internal (SPI) STAIN Curup dibentuk pada tanggal 20 September 2016 dengan ruang lingkup pengawasan pada bidang non-akademik yang meliputi: (1) bidang keuangan, (2) bidang asset, dan (3) bidang kepegawaian atau SDM. ${ }^{1}$

Setelah dibentuknya satuan pengawas internal (SPI) di STAIN Curup sejak bulan september 2017 yang lalu hingga sekarang belum dapat melaksanakan fungsinya melakukan pengawasan dan audit internal. Dikarenakan secara kelembagaan atau keorganisasian belum memiliki struktur keorganisasian, visi dan misi, wewenang dan tanggungjawab dan belum adanya panduan kinerja internal auditor yang harus dilakukan dalam rangka evaluasi terhadap kegiatan bidang nonakademik yang meliputi kegiatan perencanaan audit, pengujin dan pengevaluasian informasi, pemberitahuan hasil audit dan tindak lanjut hasil audit.

${ }^{1}$ Peraturan Menteri Agama Republik Indonesia Nomor 31 Tahun 2016 Tentang Statuta Sekolah Tinggi Agama Islam Negeri (STAIN) Curup, Dokumen Internal STAIN Curup, h. 29, 40, 41, dan 52 
Disamping itu jika dilihat dari arti pentingnya Satuan Pengawasan Intern (SPI) memiliki posisi yang sangat penting dimana satuan pengawasan internal yang dibentuk membantu terselenggaranya pengawasan terhadap pelaksanaan bidang nonakademik di STAIN Curup sebagai salah satu unit kerja di lingkungan Kementerian Agama RI. Agar sistem pemjaminan mutu dapat terlaksana dengan baik.

Untuk itu, satuan pengawas internal (SPI) harus segera didesain kelembagaannya dengan baik sehingga nantinya dapat melaksanakan fungsinya dengan baik pula. Kenapa satuan pengawas internal (SPI) STAIN Curup perlu didesain kelembagaannya? Karena satuan pengawas internal (SPI) tidak memiliki panduan kelembagaan yang baku, baik dari kementerian Agama Republik Indonesia maupun Statuta STAIN Curup. Karena satuan pengawas internal (SPI) secara kelembagaan didesain menyesuaikan dengan kebutuhan perguruan tinggi masing-masing. Dalam statuta STAIN Curup disebutkan pada bagian keempat pasal 38 ayat (6) menyatakan bahwa "ketentuan lebih lanjut Satuan Pengawas Internal (SPI) STAIN Curup ditetapkan oleh Ketua". ${ }^{2}$

\section{Masalah Yang Dihadapi}

Berdasarkan latar belakang tersebut di atas, maka dapat diidentifikasi masalah-masalah yang berkaitan dengan Sataun Pengawas Internal (SPI) STAIN Curup dalam pelaksanaan audit internal khusus di bidang nonakademik di STAIN Curup dapat dijelaskan sebagai berikut:

1. Masalah Kelembagaan : Desain Kelembagaan Satuan pengawas Internal (SPI) diserahkan kepada Rektor atau Ketua perguruan Tinggi masingmasing termasuk Ketua STAIN Curup, karena mereka yang lebih mengetahui kondisi perguruan tinggi mereka. Desain yang dimaksud tentu mempertimbngkan kebutuhan setiap perguruan tinggi masing-masing. Desain Satuan Pengawas Internal (SPI) STAIN Curup meliputi tentang misi, visi, tujuan, struktur, wewenang, tanggungjawab dan tugas serta fungsi dari masing-masing struktur kelembagaan yang dibuat.

2. Masalah Kinerja pengawasan internal (audit Internal) : Belum adanya panduan kinerja internal auditor yang harus dilakukan yang meliputi perencanaan audit, pengujian dan pengevaluasian informasi, pemberitahuan hasil audit dan tindak lanjut hasil audit.

Dari masalah yang dihadapi, maka fokus penelitian ini mengenai desain kelembagaan satuan pengawas internal yang didalamnya memuat visi dan misi, tujuan, struktur organisasi, tugas dan tanggungjawab, wewenang, tugas

${ }^{2}$ Peraturan Menteri Agama Republik Indonesia Nomor 31 Tahun 2016 Tentang Statuta Sekolah Tinggi Agama Islam Negeri (STAIN) Curup, Dokumen Internal STAIN Curup, h. 29, 40, 41, dan 52 
dan fungsi, serta kinerja pengawasan internal yang meliputi perencanaan audit, pengujin dan pengevaluasian informasi, pemberitahuan hasil audit dan tindak lanjut hasil audit.

Dengan demikian tujuan penelitian ini adalah Untuk mendapatkan hasil desain kelembagaan satuan pengawas internal (SPI) yang sesuai dengan STAIN Curup agar pengawasan dapat berjalan dengan efektif dan efisien.

\section{Konsep Dasar}

Kata Desain biasa diterjemahkan sebagai seni terapan, arsitektur, dan berbagai pencapaian kreatif lainnya. Dalam sebuah kalimat, kata "desain" bisa digunakan baik sebagai kata benda maupun kata kerja. Sebagai kata kerja, "desain" memiliki arti "proses untuk membuat dan menciptakan obyek baru". Sebagai kata benda, "desain" digunakan untuk menyebut hasil akhir dari sebuah proses kreatif, baik itu berwujud sebuah rencana, proposal, atau berbentuk obyek nyata. ${ }^{3}$

Proses desain pada umumnya memperhitungkan aspek fungsi, estetik dan berbagai macam aspek lainnya, yang biasanya datanya didapatkan dari riset, pemikiran, brainstorming, maupun dari desain yang sudah ada sebelumnya. Kata desain juga dapat digunakan dalam merancang suatu unit organisasi atau struktur organisasi. Jadi yang dimaksud desain dalam penelitian ini adalah rancangan konsep pengawasan internal yang memiliki tugas .

Satuan pengawas internal merupakan suatu perencanaan yang meliputi struktur organisasi dan semua metode dan alat-alat yang dikoordinasikan yang digunakan di dalam organisasi dengan tujuan untuk menjaga keamanan harta milik organisasi, memeriksa ketelitian dan kebenaran data akuntansi, mendorong efisiensi, dan membantu mendorong dipatuhinya kebijakan manajemen yang telah ditetapkan. ${ }^{4}$

Adapun lingkungan pengendalian dari audit internal dalam satua pengawas internal (SPI) adalah kondisi lingkungan organisasi yang sehat untuk mendukung penerapan SPI yang komponennya terdiri dari: $:^{5}$

1. Integritas dan nilai-nilai etika yang tertanam dalam budaya organisasi,

2. Komitmen terhadap kompetensi,

3. Peran dan pengaruh dewan komisaris serta komite audit,

4. Filosofi manajemen dan gaya operasi organisasi,

${ }^{3}$ Tim Penyusun Kamus Pusat Pembinaan dan Pengembangan Bahasa Departemen Pendidikan dan Kebudayaan RI., 1994, Kamus Besar Bahasa Indonesia, Edisi ke-2, Cet. Ke-4, Jakarta : Balai Pustaka, h. 225.

${ }^{4}$ Optimalisasi Peran SPI Dalam Pengawasan Di Perguruan Tinggi Oleh : Jamal Wiwoho, Inspektur Jenderal Kemristekdikti Disampaikan Dalam Forum SPIPTN Seluruh Indonesia Palangkaraya 15-16 September 2015, h. 3

IIbid. h. 9 
5. Struktur organisasi yang mampu memberikan kejelasan wewenang dan tanggung jawab dengan baik,

6. Budaya dan aturan yang sehat dalam mekanisme penetapan otoritas dan tanggungjawab,

7. Kebijakan dan praktik yang sehat di bidang sumber daya manusia.

8. Pengaruh faktor-faktor eksteren organisasi

Menurut Arens, Alder dan Beasley, mengemukakan bahwa yang dimaksud dengan audit internal adalah merupakan suatu proses penghimpunan pengevaluasian bukti-bukti mengenai informasi untuk meneliti dan melaporkan tingkat hubungan antara informasi dengan kriteria yang telah ditetapkan. Auditing ini harus dilakukan oleh orang independen dan kompeten. ${ }^{6}$

\section{Desain Kelembagaan Satuan Pengawas (SPI)}

Sesuai dengan Peraturan Menteri Agama RI Nomor 31 Tahun 2016 tentang Statuta STAIN Curup, pada Bagian Keempat Pasal 38 bahwa Satuan Pengawasan Internal (SPI) STAIN Curup merupakan unsur pengawas yang menjalankan fungsi pengawasan bidang non-akademik untuk dan atas nama Pemimpin Perguruan Tinggi. Ruang lingkup pengawasan bidang nonakademik meliputi: (1) bidang keuangan, (2) bidang asset, dan (3) bidang Sumber Daya manusia (SDM).

Satuan Pengawasan Intern merupakan satuan pengawasan yang dibentuk untuk membantu terselenggaranya pengawasan terhadap pelaksanaan tugas di STAIN Curup sebagai salah satu unit kerja di lingkungan Kementerian Agama Republik Indonesia. Dalam hal ini yang dimaksud dengan Pengawasan Intern adalah seluruh proses kegiatan audit, reviu, evaluasi, pemantauan, dan kegiatan pengawasan lain terhadap penyelenggaraan tugas dan fungsi organisasi yang bertujuan untuk mengendalikan kegiatan, mengamankan harta dan aset, terselenggaranya laporan keuangan yang baik, meningkatkan efektivitas dan efisiensi, dan mendeteksi secara dini terjadinya penyimpangan dan ketidakpatuhan terhadap ketentuan peraturan perundang-undangan.

Namun secara khusus dan spesifik dasar pembentukan Satuan Pengawas Internal dapat ditemukan pada Peraturan Menteri Agama RI Nomor 25 tahun 2017 tertanggal 04 Agustus 2017 tentang Satuan Pengawas Internal (SPI) pada Perguruan Tinggi Keagamaan Negeri.

1. Kelembagaan SPI

Ketika mendirikan sebuah organisasi, maka para pendiri biasanya akan menggagas impian atau tujuan yang ingin dicapai. Selain tujuan

${ }^{6}$ Arens, Alder dan Beasley, 2006, Auditing and Anssurance Servisce: An Integrated Approach 11th edition, h. 4 
utama, biasanya mereka memiliki gagasan mengenai target-target jangka pendek dan target jangka panjang. Untuk mewujudkan semua itu, perlu ada gagasan tertulis di dalam sebuah sistem manajemen. Visi dan misi masuk dalam bentuk-bentuk gagasan atau pedoman tertulis tersebut. Visi dan Misi harus dituangkan dalam bentuk tulisan supaya seluruh pihak mengetahui apa yang menjadi tujuan dari satuan Pengawas Internal (SPI). Adapun visi Satuan Pengawas Internal (SPI) STAIN Curup adalah "Menjadikan Satuan Pengawasan Internal yang bermutu, profesional dan independen berlandaskan ketaqwaan dan kemandirian".

Misi Adalah tahapan-tahapan yang harus dilalui untuk mencapai visi tersebut. Selain itu, misi juga merupakan deskripsi atau tujuan mengapa perusaahaan, organisasi, atau instansi tersebut berada di tengahtengah masyarakat. ${ }^{7}$ Misi juga bisa dikatakan sebagai penjabaran sebuah visi. Jika visi hanya dituliskan dalam satu kalimat saja, maka misi akan dijabarkan dengan beberapa kalimat yang mudah untuk dipahami pembaca atau siapa saja yang melihatnya. Adapu misi SPI STAIN Curup memiliki misi sebagai berikut :

a. Melaksanakan pengawasan internal atas aktivitas manajemen disemua unit kerja dilingkungan STAIN Curup terutama dibidang nonakademik (keuangan, aset, dan Sumber Daya manusia (SDM).

b. Mendorong peningkatan kinerja Perguruan Tinggi (STAIN Curup) sebagai pelayan publik yang profesional.

c. Menjadi mitra strategis bagi manajemen perguruan Tinggi dalam memberikan nilai tambah pada proses penyelenggaraan STAIN Curup terutama bidang non akademik.

d. Membantu pimpinan untuk mendapatkan penilaian yang obyektif dan berkualitas atas pelaksanaan kegiatan dimasing-masing unit kerja di lingkungan STAIN Curup bidang non akademik.

e. Mendorong pimpinan STAIN Curup untuk meningkatkan penerapan tata kelola Lembaga yang baik (good governance).

f. Meningkatkan kompetensi SDM dan kapabilitas organisasi SPI.

Setelah adanya visi dan misi, selanjutnya adalah tujuan. Tujuan juga merupakan misi atau sasaran yang ingin dicapai oleh suatu organisasi di masa yang akan datang. Jadi tujuan merupakan kunci untuk menentukan atau merumuskan apa yang akan dikerjakan, ketika pekerjaan itu harus dilaksanakan dan disertai pula dengan jaringan prosedur, anggaran serta

${ }^{7}$ Hendrawan Supratikno, 2003, Advanced Strategic Management: Back to Basic Approach, Jakarta: PT Gramedia Pustaka Utama, h. 27 
penentuan program. Satuan Pengawas Internal (SPI) STAIN Curup memiliki tujuan ${ }^{8}$, sebagai berikut:

1. Menjamin terselenggaranya tata kelola setiap satuan kerja STAIN Curup berjalan sesuai dengan ketentuan peraturan perundangundangan yang berlaku;

2. Memastikan tercapainya tujuan setiap satuan kerja STAIN Curup secara optimal;

3. Memastikan pengelolaan setiap satuan kerja STAIN Curup berdasarkan prinsip ekonomi, efisiensi, efektivitas, produktivitas, dan penerapan praktik bisnis yang sehat;

4. Menjamin pengelolaan dan keamanan aset satuan kerja STAIN Curup ; dan

5. Menjamin terwujudnya pelaporan keuangan yang handal dan/atau sesuai dengan peraturan perundangan.

Selanjutnya dilihat dari Kedudukan dan Tanggung Jawab, dapat dikemukakan bahwa Satuan Pengawasan Internal (SPI) STAIN Curup berkedudukan di bawah dan bertanggung jawab kepada Ketua STAIN Curup. Tugas yang diemban oleh SPI STAIN Curup :

a. Bertugas melaksanakan pengawasan nonakademik pada STAIN Curup.

b. Dalam melaksanakan tugas pengawasan, SPI menjunjung tinggi prinsip integritas, objektif, keahlian, dan menjaga kerahasiaan.

c. Memberikan analisa penilaian, rekomendasi, konsultasi dan informasi mengenai aktivitas yang diaudit sesuai dengan yang disyaratkan oleh kode etik dan standar profesi internal audit.

Disamping itu, SPI berfungsi :

a. penyusunan peta risiko pengendalian internal melalui kegiatan identifikasi, penilaian risiko, penentuan skala prioritas, dan pemantauan;

b. penyusunan program dan kegiatan pengawasan nonakademik;

c. pelaksanaan pengawasan kepatuhan, kinerja, dan mutu nonakademik di bidang sumber daya manusia, perencanaan, keuangan, organisasi, teknologi informasi, serta sarana dan prasarana;

d. penyusunan perencanaan dan pelaksanaan pemeriksaan dengan tujuan tertentu;

e. penyusunan dan penyampaian laporan hasil Pengawasan Internal;

f. pemantauan dan pengoordinasian tindak lanjut hasil Pengawasan Internal dan eksternal; dan

g. pelaksanaan fungsi lain yang diberikan oleh Pemimpin PTKN. 
Dalam hal kewenangan yang dimiliki oleh SPI STAIN Curup dikemukakan pada pasal 6 dimana SPI memiliki kewenangan:

a. Menentukan prosedur dan ruang lingkup pelaksanaan pengawasan; Memperoleh akses tidak terbatas atas seluruh dokumen, data, informasi, dan objek pemeriksaan pada unit kerja; Melakukan penelitian, verifikasi, pengujian, analisis, konfirmasi, dan penilaian atas dokumen, data, dan informasi berkaitan dengan objek pemeriksaan internal;

b. Menggunakan tenaga ahli/auditor dari luar SPI jika diperlukan;

c. Melakukan pendampingan dan koordinasi dengan aparat pengawas intern pemerintah dan pemeriksa eksternal.

d. Melakukan reviu, audit, evaluasi, pemantauan dan kegiatan pemeriksaan lainnya dalam nonakademik;

e. Menindaklanjuti laporan atas dugaan terjadinya penyalahgunaan wewenang;

f. Mewakili pimpinan STAIN Curup dan/atau Direktorat Jenderal Pendidikan Islam dalam melakukan pengendalian internal;

2. Struktur Organisasi SPI

Struktur organisasi adalah konfigurasi peran formal yang didalamnyadimaksudkan sebagai prosedur, governansi dan mekanisme kontrol, kewenangan serta proses pengambilan kebijakan. Sesuai kedudukannya, SPI STAIN Curup merupakan organ pengawasan Perguruan Tinggi yang berada di bawah dan bertanggung jawab langsung kepada Ketua. Dalam melaksanakan fungsinya, SPI dipimpin oleh seorang Kepala dengan dibantu seorang sekretaris dan para koordinator bidang. Pada tahap awal, bidang-bidang SPI meliputi bidang keuangan, bidang sumber daya manusia, bidang dan barang milik negara, serta bidang Pengembangan, Perencanaan dan Evaluasi. Di masa mendatang bidangbidang ini dapat dikembangkan sesuai kebutuhan STAIN Curup.

Struktur organisasi yang baik untuk bagian auditor internal adalah struktur yang menempatkan bagian tersebut berada langsung di bawah dan tanggung jawab pimpinan yang bertanggung jawab terhadap seluruh personal organisasi yang memiliki kewewenangan untuk mewujudkannya. Pemisahan peran dan status organisasi dapat membebaskan auditor internal dari suatu kecenderungan emosional terhadap pihak yang diperiksa. Auditor internal dapat dikatakan independen jika ia dapat bekerja secara bebas dan objektif.

Sesuai dengan Peraturan Menteri Agama Republik Indonesia tentang Satuan Pengawas Internal (SPI) Perguruan Tinggi Keagamaan Negeri (PTKN) di lingkungan kementerian agama pada Bab V pasal 7 
pada ayat (1) disebutkan bahwa organ SPI Paling kecil terdiri dari : a. Kepala; b. Sekretaris; dan Anggota.

Pada ayat (2) Jumlah anggota sebagaimana dimaksud pada ayat (1) huruf c disesuaikan dengan kebutuhan. Pada ayat (3) Kepala SPI pada PTKN berbentuk universitas/institut disetarakan dengan Ketua Lembaga, dan Kepala SPI pada sekolah tinggi disetarakan dengan Kepala Pusat. Pada ayat (4) Organ SPI sebagaimana dimaksud pada ayat (1), diangkat dari Pegawai Negeri Sipil, bukan Pegawai Negeri Sipil, dan/atau tenaga profesional. Pada ayat (5) SPI paling sedikit memiliki anggota yang menguasai:

a. pencatatan dan pelaporan keuangan;

b. tata kelola perguruan tinggi;

c. peraturan perundang-undangan di bidang pendidikan tinggi; dan

d. pengelolaan barang milik negara.

Istilah organisasi mempunyai dua pegertian umum, Pertama organisasi diartikan suatu lembaga atau kelompok fungsional, misalnya sebuah perusahaan, sebuah sekolah, sebuah perkumpulan, badan-badan pemerintahan. Kedua merujuk pada proses pengorganisasian yaitu bagaimana pekerjaan diatur dan dialokasikan diantara para anggota, sehigga tujuan organisai dapat tercapai secara efektif. ${ }^{9}$

Struktur organisasi SPI yang sesuai dengan kebutuhan STAIN Curup sebagaiman di bawah ini :

Kepala SPI

Sekretaris SPI

Korbid. Keuangan, BMN, dan Hukum

Korbid. SDM,PPE, dan Audit Khusus

Tenaga Administrasi

\section{Kinerja Auditor Internal ${ }^{10}$}

Menurut Arens, Alder dan Beasley, mengemukakan bahwa yang dimaksud dengan audit internal adalah merupakan suatu proses penghimpunan pengevaluasian bukti-bukti mengenai informasi untuk meneliti dan melaporkan tingkat hubungan antara informasi dengan kriteria yang telah ditetapkan. Auditing ini harus dilakukan oleh orang independen dan kompeten. ${ }^{11}$

${ }^{9}$ Nanang Fattah, Landasan Manjemen Pendidikan, (Bandung: PT. Remaja Rosdakarya, 2006), Cet. VIII, h. 71.

${ }^{10}$ Hiro Tugiman, 1997, Standar Profesi Audit Internal, Yogyakarta: Penerbit Kanisius, h. 11

${ }^{11}$ Arens, Alder dan Beasley, 2006, Auditing and Anssurance Servisce: An Integrated Approach 11th edition, h. 4 
Untuk melihat kinerja Audit Internal dapat dilihat dari kompetensi. dapun ompetensi yang harus dimiliki oleh Auditor Internal adalah :

a. Pengetahuan : Auditor internal harus memiliki pengetahuan terhadap bidang tugasnya, pengetahuan yang terkait dengan lingkup auditnya, serta pengetahuan teknis tentang audit. Selain itu, latar belakang pendidikan auditor sangat menentukan keahlian dan kompetensi seorang auditor.

b. Keahlian : Kemahiran profesional diperoleh melalui pendidikan yang berkelanjutan sesuai dengan bidang tugasnya untuk memenuhi kebutuhan pengembangan profesinya serta meningkatkan keahliannya. Auditor internal didorong untuk meningkatkan keahliannya dengan mengikuti program pendidikan bersertifikasi profesi. Sertifikasi profesi tersebut akan meningkatkan keahlian dan kompetensi seorang auditor.

c. Pengalaman : Pengalaman merupakan cara pembelajaran yang baik bagi auditor internal untuk menjadikan auditor kaya akan teknik audit. Semakin tinggi pengalaman auditor, maka semakin mampu dan mahir auditor mengusai tugasnya sendiri maupun aktivitas yang diauditnya.

Tahapan pelaksanaan Audit harus mencakup :

a. Tahap perencanaan audit

b. Tahap pengujian dan pengevaluasian informasi

c. Tahap penyampaian hasil audit

d. Tahap tindak lanjut (follow up) hasil audit

1. Perencanaan Audit

Tahap perencanaan audit merupakan langkah yang paling awal dalam pelaksanaan kegiatan audit intenal, perencanaan dibuat bertujuan untuk menentukan objek yang akan diaudit/prioritas audit, arah dan pendekatan audit, perencanaan alokasi sumber daya dan waktu, dan merencanakan hal-hal lainnya yang berkaitan dengan proses audit. Audit intern haruslah merencanakan setiap pemeriksaan. Perencanaan haruslah didokumentasikan yang meliputi:

a. Pada tahap perencanaan perlu ditetapkannya tujuan dan lingkup pekerjaan.

b. Peroleh informasi dasar (background information) tentang kegiatankegiatan yang akan diperiksa.

c. Penentuan berbagai tenaga yang diperlukan untuk melaksanakan audit.

d. Pemberitahuan kepada para pihak yang dipandang perlu.

e. Melaksanakan survey untuk mengenali kegiatan yang diperlukan, risikorisiko dan pengawasan-pengawasan.

f. Penulisan program audit.

g. Menentukan bagaimana, kapan dan kepada siapa hasil-hasil audit akan disampaikan.

h. Memperoleh persetujuan bagi rencana kerja audit. 
i. Berbagai keperluan pelaksanaan audit lainnya, seperti jangka waktu pelaksanaan audit, luas periode yang akan diaudit, dan perkiraan saat selesainya audit, haruslah ditentukan. Harus pula dipertimbangkan bentuk laporan audit final karena perencanaan yang tepat pada tahap ini akan memnudahkan penulisan laporan audit yang final.

j. Penentuan berbagai tenaga yang diperlukan untuk melaksanakan audit.

k. Jumlah dan tingkat pengalaman staf audit yang diperlukan haruslah didasarkan pada evaluasi sifat dan tingkat kesulitan dari tugas audit, batas waktu penyelesaian, dan tenaga yang tersedia.

1. Haruslah dilakukan rapat dengan manajemen yang bertanggungjawab terhadap kegiatan yang akan diaudit. Hal-hal yang akan didiskusikan dapat mencakup:

a) Berbagai tujuan dan lingkup kerja audit yang direncanakan.

b) Waktu pelaksanaan audit.

c) Para auditor yang akan ditugaskan.

d) Proses pembicaraan selama audit, termasuk metode yangdigunakan, susunan waktu dan individu-individu yangakan bertanggungjawab.

e) Keadaan dan pelaksanaan usaha pada kegiatan yang akandiaudit, termasuk berbagai perubahan yang baru saja terjadidalam manajemen atau system yang pokok.

f) Berbagai perhatian atau permintaan kepada manajemen.

g) Hal-hal yang merupakan kepentingan khusus ataumenjadi perhatian auditor internal.

h) Gambaran tentang berbagai prosedur pelaporan dan prosestindak lanjut oleh bagian audit internal.

2. Pengujian dan Pengevaluasian Informasi

Pada tahap ini audit intern haruslah mengumpulkan, menganalisa, menginterprestasi dan membuktikan kebenaran informasi untuk mendukung hasil audit. Untuk melaksanakan audit, diperlukan informasi yang dapat diverifikasi dan sejumlah standard (criteria) yang digunakan sebagai pegangan dalam pengevaluasian informasi tersebut. Informasi harus dapat diukur agar dapat diverifikasi. Informasi memiliki berbagai bentuk, sedangkan kriteria untuk mengevaluasi informasi kuantitatif cukup beragam dan audit perlu dilakukan oleh orang yang kompeten.

Seorang auditor internal harus memiliki kemampuan pemahaman akan kriteria yang digunakan, serta mampu menentukan jumlah bukti yang diperlukan untuk mendukung kesimpulan yang diambilnya. Auditor harus mempunyai sikap mental yang independen (independent mental attitude). Sekalipun ia ahli, apabila tidak mempunyai sikap independen dalam mengumpulkan informasi akan menjadi tidak berguna, sebab informasi yang digunakan untuk pengambilan keputusan menjadi bias. 
3. Penyampaian Hasil Pemeriksaan

Auditor Internal harus melakukan hasil audit yang dilaporkannya. Audit Internal haruslah mengumpulkan, menganalisis, menginterpretasi, dan membuktikan kebenaran informasi untuk mendukung hasil audit. ${ }^{12}$ Laporan audit internal ditujukan untuk kepentingan manajemen yang dirancang untuk memperkuat pengendalian audit intern, untuk menentukan ditaati tidaknya prosedur atau kebijakan-kebijakan yang telah ditetapkan oleh manajemen. Audit intern harus melaporkan kepada manajemen apabila terdapat penyelewengan atau penyimpangan yang terjadi di dalam suatu fungsi organisasi dan memberikan saran-saran dan rekomendasi untuk perbaikannya.

Proses pengujian dan pengevaluasian informasi adalah sebagai berikut:

a) Laporan tertulis yang ditandatangani haruslah dikeluarkan setelah pengujian terhadap audit (audit examination) selesai dilakukan. Laporan sementara dapat dibuat secara tertulis atau lisan dan diserahkan secaraformal atau informal.

b) Audit Internal harus terlebih dahulu mendiskusikan berbagai kesimpulan dan rekomendasi dengan tingkatan manajemen yang tepat, sebelum mengeluarkan laporan akhir.

c) Suatu laporan haruslah objektif, jelas, singkat, konstruktif, dan tepatwaktu.

d) Laporan haruslah mengemukakan tentang maksud, lingkup, dan hasilpelaksanaan audit, dan bila dipandang perlu, laporan harus pulaberisikan pernyataan tentang pendapat auditor.

e) Laporan-laporan dapat mencantumkan berbagai rekomendasi bagiberbagai perkembangan yang mungkin dicapai, pengakuan terhadapkegiatan yang dilaksanakan secara meluas dan tindakan korektif.

f)Pandangan dari pihak yang diperiksa tentang berbagai kesimpulan atas rekomendasi dapat pula dicantumkan dalam laporan audit.

g) Pimpinan audit internal atau staff yang ditunjuk harus me-review dan menyetujui laporan audit akhir, sebelum laporan tersebut dikeluarkan, dan menentukan kepada siapa laporan tersebut akan disampaikan.

4. Tindak Lanjut Hasil Pemeriksaan

Audit intern harus terus menerus meninjau dan melakukan tindak lanjut (follow up) untuk memastikan bahwa terhadap temuan-temuan pemeriksaan yang dilaporkan telah dilakukan tindakan yang tepat. Audit intern harus memastikan apakah suatu tindakan korektif telah dilakukan

${ }^{12}$ Harahap, 1991, Auditing Kontemporer, edisi satu, Jakarta: Erlangga, h. 167 
dan memberikan berbagai hasil yang diharapkan. Tindak lanjut oleh Audit Internal didefinisikan sebagai suatu proses untuk menentukan kecukupan, keefektifan, dan ketepatan waktu dariberbagai tindakan yang dilakukan oleh manajemen terhadap berbagaitemuan audit yang dilakukan. Suatu temuan dapat mencakup berbagai temuan lain yang relevan yang didapat oleh auditor dan lainnya.

a) Tanggungjawab untuk melakukan tindak lanjut harus didefinisikan dalam ketentuan, kewenangan, dan tanggung jawab bagi Audit Internal.

b) Manajemen bertanggung jawab menetukan tindakan yang perludilakukan sebagai tanggapan terhadap temuan audit yang dilaporkan. pimipnan Audit Internal bertanggung jawab memperkirakan tindakan manajemen yang diperlukan, agar berbagai hal yang dilaporkan sebagai temuan audit tersebut dapat dipecahkan secara tepat waktu.

c) Dalam menentukan luas dari tindak lanjut, Audit Internal harusmempertimbangkan berbagai prosedur dari hal-hal yang berkaitandengan tindak lanjut, yang dilaksanakan oleh pihak lain dalamorganisasi.

d) Manajemen senior dapat menetapkan untuk menerima resiko akibat tidak dilakukannya tindakan korektif terhadap keadaan yang dilaporkan, berdasarkan pertimbangan biaya atau pertimbangan lainnya. Dewan harus diberi laporan tentang seluruh keputusan manajemen senior terhadap berbagai temuan audit penting.

e) Sifat, ketepatan waktu, dan luas tindak lanjut ditentukan oleh pimpinan Audit Internal.

f) Berbagai faktor yang harus dipertimbangkan dalam menentukan berbagai prosedur tindak lanjut yang tepat adalah pentingnya temuan yang dilaporkan, tingkat usaha dan biaya yang dibutuhkan, resiko yang mungkin terjadi, tingkat kesulitan pelaksanaan, jangka waktu yang dibutuhkan.

g) Beberapa temuan tertentu yang dilaporkan mungkin sangat penting dan segera memerlukan tindakan manajemen. Kondisi tersebut harus terus dimonitor oleh Audit Internal hingga diperbaiki karena berbagai akibat yang mungkin ditimbulkan organisasi.

h) Terdapat pula berbagai keadaan dimana pimpinan Audit Internal menilai bahwa tindakan yang dilakukan oleh manajemen telah cukup,bila dibandingkan dengan pentingnya temuan audit. Dalam halhal tertentu, tindak lanjut dapat dilaksanakan sebagai bagian dari audityang akan diadakan kemudian. 
i) Auditor harus memastikan bahwa tindakan yang dilakukan terhadap temuan audit memperbaiki berbagai kondisi yang mendasari dilakukannya tindakan tersebut.

j) Pimpinan unit Audit Internal bertanggungjawab membuat jadwal kegiatan tindak lanjut sebagai bagian dari pembuatan jadwal pekerjaan audit.

k) Penjadwalan tindak lanjut harus didasarkan pada resiko dan kerugian yang terkait, juga tingkat kesulitan dan perlunya ketepatan waktu dalam penerapan tindakan korektif.

1) Pimpinan audit harus menetapkan berbagai prosedur seperti jangka waktu bagi manajemen dalam menyampaikan tanggapan, mengevaluasi tanggapan manajemen, mengadakan verifikasi terhadaptanggapan manajemen, pemeriksaan terhadap tindak lanjut audit.

Berbagai teknik yang dipergunakan untuk menyelesaikan tindak lanjut secara efektif adalah sebagai berikut:

a) Pengiriman laporan tentang temuan audit kepada tingkatmanajemen yang tepat.

b) Menerima dan mengevaluasi tanggapan manajemen terhadap temuan audit selama pelaksanaan audit, atau dalam jangka waktuyang wajar setelah laporan hasil audit diterbitkan.

c) Menerima laporan perkembangan perbaikan dari manajemensecara periodik.

d) Menerima dan mengevaluasi laporan dari berbagai organisasi lain yang ditugaskan dan bertanggungjawab mengenai berbagai hal yang berhubungan dengan proses tindak lanjut.

e) Melaporkan kepada manajamen atau dewan tentang status tanggapan terhadap berbagai temuan audit.

5. Laporan Audit Internal

Penyusunan laporan audit merupakan alat untuk menyampaikan informasi kepada para pemakai laporan tersebut. Pada hakekatnya laporan tersebut harus mampu memberikan informasi mengenai kesesuaian informasi-informasi yang diperiksa dengan kriteria yang telah ditetapkan.

Hasil akhir dari pelaksanaan audit internal dituangkan dalam suatu bentuk laporan tertulis melalui proses penyusunan yang baik dan teratur. Laporan ini merupakan suatu alat penting untuk menyampaikan pertanggungjawaban kepada manajemen.

Tahap terakhir dalam proses audit adalah menyiapkan laporan audit yang menyampaikan temuan-temuan auditor kepada pemakai. Laporan seperti ini memiliki sifat yang berbeda-beda, tetapi semuanya harus memberi tahu para pembaca tentang derajat kesesuaian antara informasi dan kriteria yang telah ditetapkan. Laporan juga memiliki bentuk yang 
berbeda dan dapat bervariasi mulai dari jenis yang sangat teknis yang biasanya dikaitkan dengan audit laporan keuangan hingga laporan lisan yang sederhana dalam audit operasional atas efektivitas suatu unit.

Auditor internal harus melaporkan hasil-hasil pemeriksaan yang dilakukannya atau yang diperoleh dari kegiatan pemeriksaannya. Proses penyampaian hasil pemeriksaan meliputi hal-hal sebagai berikut:

Auditor internal harus terlebih dahulu mendiskusikan berbagai kesimpulan dan rekomendasi dengan tingkatan manajemen yang tepat, sebelum mengeluarkan laporan akhir.

a. Laporan harus objektif, jelas, singkat, konstruktif dan tepat waktu.

b. Laporan harus mengemukakan tentang maksud, lingkup dan hasil pelaksanaan pemeriksaan.

c. Laporan dapat mencantumkan berbagai rekomendasi bagi berbagai perkembangan yang mungkin dicapai, pengakuan terhadap kegiatan yang dilaksanakan secara meluas dan tindakan korektif.

d. Pandangan dari pihak yang diperiksa tentang berbagai kesimpulan atau rekomendasi.

e. Pengujian auditor internal dan staf yang ditunjuk harus mereviu dan menyetujui laporan pemeriksaan akhir, sebelum laporan tersebut akan disampaikan.

f. Laporan Auditor internal harus melaporkan hasil-hasil pemeriksaan yang dilakukannya atau yang diperoleh dari kegiatan pemeriksaannya.

Sebagai hasil dari audit internal harus membuat laporan kepada manajemen. Laporan tersebut merupakan suatu alat dan kesempatan bagi internal auditor untuk menarik perhatian manajemen dan membuka mata manajemen mengenai manfaat dari Internal Audit. Untuk itu laporan hasil audit harus : Objectif, Clear (jelas), singkat tetapi padat, Membangun, dan Cepat waktu

6. Kualitas Pelaksanaan Audit

Standard pelaksanaan audit menguraikan tiap kegiatan yang sangat diperlukan pada pemeriksaan, yaitu merencanakan pemeriksaan, menguji dan menilai bahan pembuktian dan mengkomunikasikan hasilnya. Auditor internal bertanggung jawab untuk merencanakan dan melaksanakan tugas pemeriksaan, yang harus disetujui dan ditinjau atau direviu oleh atasan auditor. Auditor internal harus terus menerus meninjau atau melakukan tindak lanjut (follow up) untuk memastikan bahwa rekomendasi terhadap temuan-temuan pemeriksaan yang dilaporkan telah diambil tindakan yang tepat. Auditor internal juga harus memastikan apakah suatu tindakan korektif yang diusulkan memberikan berbagai hasil yang diharapkan. Apabila tidak ada follow up atas temuan pemeriksaan maka berarti 
manajemen telah menerima risiko akibat tidak dilakukannya tindakan korektif atas temuan yang dilaporkan.

Untuk menciptakan hasil audit internal yang berkualitas harus di control hal-hal yang merupakan keterbatasan Pengedalian internal. Beberapa keterbatasan pengendalian internal yang melemahkan keberadaan pengendalian, diataranya sebagai berikut : Kesalahan dalam pertimbangan, Gangguan, Kolusi, Pengabaian oleh manajemen, dan Biaya lawan manfaat. Di samping itu pelaksanaanya harus Independensi dan Objektivitas.

\section{Penutup}

Dari paparan di atas dan hasil analisa data-data yang diperoleh dan kumpulkan :

1. Keberadaan Satuan Pengawas Internal di STAIN Curup merupakan suatu keharusan terlehih lagi setelah keluarnya Peraturan Menteri Agama RI Nomor 25 tahun 2017 tertanggal 04 Agustus 2017 tentang Satuan Pengawas Internal (SPI) pada Perguruan Tinggi Keagamaan Negeri.

2. SPI memiliki kewenangan: Menentukan prosedur dan ruang lingkup pelaksanaan pengawasan; Memperoleh akses tidak terbatas atas seluruh dokumen, data, informasi, dan objek pemeriksaan pada unit kerja; Melakukan penelitian, verifikasi, pengujian, analisis, konfirmasi, dan penilaian atas dokumen, data, dan informasi berkaitan dengan objek pemeriksaan internal. Kinerja Auditor Internal satuan pengawas internal (SPI ) STAIN Curup dapat dilihat dari empat pelaksanaan audit, yaitu : Tahap perencanaan audit, Tahap pengujian dan pengevaluasian informasi, Tahap penyampaian hasil audit, Tahap tindak lanjut (follow up) hasil audit. 


\section{Daftar Pustaka}

Arens, Alder dan Beasley, 2006, Auditing and Anssurance Servisce: An Integrated Approach 11th edition.

Arens, Alder dan Beasley, 2006, Auditing and Anssurance Servisce: An Integrated Approach 11th edition.

Harahap, 1991, Auditing Kontemporer, edisi satu, Jakarta: Erlangga.

Hendrawan Supratikno, 2003, Advanced Strategic Management: Back to Basic Approach, Jakarta: PT Gramedia Pustaka Utama.

Hiro Tugiman, 1997, Standar Profesi Audit Internal, Yogyakarta: Penerbit Kanisius.

Manullang.1990. Dasar-Dasar Manajemen. Jakarta: Ghalia Indonesia.

Nanang Fattah, Landasan Manjemen Pendidikan, (Bandung: PT. Remaja Rosdakarya, 2006), Cet. VIII.

Optimalisasi Peran SPI Dalam Pengawasan Di Perguruan Tinggi Oleh : Jamal Wiwoho, Inspektur Jenderal Kemristekdikti Disampaikan Dalam Forum SPIPTN Seluruh Indonesia Palangkaraya 15-16 September 2015.

Peraturan Menteri Agama Republik Indonesia Nomor 31 Tahun 2016 Tentang Statuta Sekolah Tinggi Agama Islam Negeri (STAIN) Curup, Dokumen Internal STAIN Curup.

Peraturan Menteri Agama Republik Indonesia Nomor 31 Tahun 2016 Tentang Statuta Sekolah Tinggi Agama Islam Negeri (STAIN) Curup, Dokumen Internal STAIN Curup.

Tim Penyusun Kamus Pusat Pembinaan dan Pengembangan Bahasa Departemen Pendidikan dan Kebudayaan RI., 1994, Kamus Besar Bahasa Indonesia, Edisi ke-2, Cet. Ke-4, Jakarta. 
106 | TADBIR : Jurnal Studi Manajemen Pendidikan, Vol. 2, No. 1, 2018

This page belongs to the TADBIR : Jurnal Studi Manajemen Pendidikan TADBIR : Jurnal Studi Manajemen Pendidikan vol. 2 , no. 1, 2018

STAIN Curup - Bengkulu | p-ISSN 2580-3581; e-ISSN 2580-5037 